\title{
EFFECT OF MAGNETIZED WELL WATER ON BLOOD COMPONENTS, IMMUNE INDICES AND SEMEN QUALITY OF EGYPTIAN MALE GEESE
}

\author{
A. M. El-Hanoun'; Wesam A. Fares'; Y. A. Attia ${ }^{2,3}$; and M.M. Abdella ${ }^{1}$ \\ ${ }^{\mathbf{1}}$ Anim. Prod. Res. Inst., Agric. Res. Center, Egypt. \\ ${ }^{2}$ Anim. and Poult. Prod. Dep., Fac. of Agric., Damanhour Univ., Egypt. \\ ${ }^{3}$ Arid Land Agric. Dep., Fac. of Meteorology, Envir. and Arid Land Agric., King Abdulaziz \\ Univ., P.O. Box 80208, Jeddah 21589, Saudi Arabia. \\ Corresponding author: Ali M. El-Hanoun; Email:alielhanoun@yahoo.com
}

Received:15/01/2017 Accepted:01/02/2017

ABSTRACT: The present study was carried out to study the effect of exposing tap water and well water to magnetic fields on blood components, immunity indices and the semen of Egyptian geese. Sixty four one year-old male geese were randomly divided into four equal groups, each made up of four replicates of 4 ganders. The treatments included tap water (TW) as group 1 and well water (WW) as groups 2 . The well water was offered with exposure to a magnetic field of 4000 gauss (MWW 4000; group 3) or of 6000 gauss (MWW $_{6000}$; group 4). During the experiment, the ganders of all groups were kept in an intensive system, with confinement in a house, and fed a commercial mash feed ad libitum. Natural mating was practiced from November 2015 to the end of May 2016. The well water had poor quality. Magnetic treatment improved the quality of the well water, with 6000 gauss having a stronger effect than 4000 gauss. The genders who drank WW showed significantly $(\mathrm{p} \leq 0.05)$ poor semen quality, reproductive traits, testosterone hormone besides renal and liver function. Magnetizing the well water improved semen quality, reproductive traits, functions of kidney and liver, antioxidant status and immune response with a more favourable influence of 6000 than 4000 gauss. Thus, magnetizing well water, particularly with 6000 gauss, may offer a possible solution for improving the physiological and immunological traits of geese receiving well water.

Key words: Geese- Magnetic water- Semen quality- Blood components- Immunity. 


\section{INTRODUCTION}

Water is the energy of life, it transports fluids and nutrients via the blood, maintains cellular structural integrity, regulates body temperature (Marai et al., 2005). In Egypt, fresh water in the desert is very rare, which represents a serious problem for the expanding and developing animal and poultry farms (Hassan, 2013). In Egypt, desert areas depend on underground water for animals reared in farms that are erected in desert lands to drink. Salinity in well water, particularly in the desert area, is a common problem. Animals in these areas usually drink well water with varying degrees of salinity. This water often contains high concentrations of dissolved salts, and some minerals which consider toxic, causing a reduction in productive and physiological performance (Attia et al., 2015). Soliman (1993) and Ezzat (1999) declared that liver and kidney functions decreased by increasing the salt level in the drinking water for broiler chickens. Blood parameters and minerals are changed by drinking saline water (Fayez et al., 1994). Zaghloul et al. (2011) found that rams drinking saline water experienced adverse effects on semen quality characteristics. Both hydrogen wings and the oxygen body of the water molecule show individual opposite charges and tend to attract each other, while the water molecule as a whole has no charge (Kegley and Andrews, 1998). Principle for the magnetic technology is a result of the physics of interaction between a magnetic field and a moving electric charge, in this case in the form of ion. When ions pass through the magnetic field, a force is exerted on each ion. The forces on ions of opposite charges are in opposite directions (Lock, 1986). In addition, magnetic or electrostatic scale technologies can be used as a replacement for chemical softening (lime or lime-soda softening), ion exchange, and reverse osmosis for improving water quality. It could also be used for the control of hardness and to replace nonchemical water conditioning technology for both cooling and boiling water treatments (Lam, 2001; and Smith, 2005).

The mineral content of water may be changed with exposure to strong magnetic fields, and the quality can be improved by increasing the magnetic field over a more prolonged time than by a weak magnetic field over a shorter duration (Lam, 2001). Magnetic treatment changes the mineral contents of water, thus increasing its permeability through biological membranes (Lin and Yotvat, 1989). The use of magnets to improve water quality is nowadays of significant interest due to its low cost compared to chemical and physical treatments. In this regard, exposing water to a magnetic field causes an increase in the solubility of calcium salts, which decreases limescale deposits in pipes and also cleans pipes from deposited limescale (Verma, 2011).

The source and quality of water has been shown to influence animal performance, limit the extension of animal production, and increase health hazards (Scollanet al., 2010). Moreover, Mustafa (2007) observed that chickens who drank magnetized water showed significantly better fertility, hatchability, viability, and thyroid hormone levels, but lower corticosterone (Zhao et al., 2002). Al-Daraji and Aziz (2008 and 2009) reported that cocks who drank water exposed to 2000 gauss had improved semen quality and biochemical constituents of seminal plasma, while they had fewer dead spermatozoa, abnormal spermatozoa and acrosomal abnormalities than those who drank unexposed water. El-Hanoun (2014) found that exposing water, and particularly well water, to a magnetic field improved the productive and reproductive performance and antioxidant status of female Egyptian geese and their offspring. This study aimed to test the influences of drinking well water exposed to magnetic treatment on the blood components, 
immunity, and semen quality of Egyptian geese.

\section{MATERIALS AND METHODS}

\section{Birds and the experimental design:}

This experiment was conducted at a private commercial farm in a desert area (Musa farm) in Nubaria City, El-Behera Governorate, Egypt from November 2015 until May 2016, thus lasting 28 weeks. A flock of 64 Egyptian male geese (aged one year-old) were used in this experiment. Ganders were randomly divided into four equal treatment groups (16 males in each) and distributed among four equal replicates of 4 males each. Ganders were housed in windowless houses furnished with wood shaving as litter that contained sixteen pens of $2.5 \times 2.5 \mathrm{~m}^{2}$. During the daytime, the ganders were exposed to natural light. Ganders of all groups were kept in an intensive system, with confinement in a house, and fed ad libitum a commercial mash feed containing 15\% CP, $2700 \mathrm{kcal}$ $\mathrm{ME} / \mathrm{kg}, \quad 2.5 \mathrm{Ca}, \quad 0.30 \%$ inorganic phosphorus, $0.60 \%$ methionine + cystine, and $0.70 \%$ lysine (AOAC, 2007). At the beginning of the experiment, all geese were vaccinated against avian influenza. Ganders were submitted to the following treatments groups: those who drank tap water (TW, group 1); those who drank well water (WW, group 2); those who drank well water exposed to a magnetic field of 4000 gauss (MWW 4000 , group 3); and those who drank well water exposed to a magnetic field of 6000 gauss (MWW 6000, group 4). The well water was obtained from a well at Nubaria city with a depth of 150 meters, and the TW was obtained from the same city.

\section{Physical and chemical analysis of the water:}

The physical characteristics of water were determined using Jenway $3505 \mathrm{pH}$ Meter and Jenway 4150 conductivity Meter (Staffordshire, UK). The element analyses of water were carried out using $\mathrm{Dr}$ 3900HACH Lange, Spectrophotometer and FIAstar 5000 Analyser, Model FO 55
(CA, USA) and Flame photometer (Spectronic 20, Maharashtra, India). The results are shown in Table 1.

Water was exposed to magnetic field by a permanent magnet in a compact form using a unit called Aqua Correct (magnetic water softeners and conditioners, Blue Goose Sales, 200 S Duane Ct, Post Falls ID 83854, USA). This equipment is a permanent coaxial system that produced magnetic field strengths as high as 4000 and 6000 gauss. The function is pure physical magnetic. Its purpose is that the crystal structure of limescale will change so it can be easily removed. The strength of the magnet was measured by Teslameter (F.W.Bell/ Gauss, Model 5070, USA) at Application Laboratory, City for Scientific Research and Biotechnology,

\section{Blood biochemical constituents, immunity, and antioxidant status:}

Heparinised tubes were used to collect blood samples $(n=16$ samples per treatment) obtained from the wing vein of each gander at the end of the experiment. Blood samples were centrifuged at 3500 rpm for 20 min to obtain plasma and stored at $-20{ }^{\circ} \mathrm{C}$ for later analysis. Red blood cells $\left(\mathrm{RBCs} \times 10^{6} \mathrm{~mm}^{3}\right)$, haemoglobin $(\mathrm{Hb} \mathrm{g} / \mathrm{dl})$, haematocrit $(\mathrm{Ht} \%)$, and cellular immunity (white blood cells $\times 10^{3} / \mathrm{mm}^{3}$, lymphocyte \%, monocyte $\%$, eosinophil\%, basophil\%) were determined according to Hepler (1966) and Eilers (1967). The $\mathrm{MCV}, \mathrm{MCH}$ and $\mathrm{MCHC}$ were calculated according to Hepler (1966). The white blood cells were measured according to Lucas and Jamroz (1961). Different types of immunoglobulins ( $\operatorname{IgG}, \operatorname{IgM}$ and $\operatorname{IgA}$ ) in the blood serum were determined $(n=5$ samples per treatment) using commercial ELISA kits (Kamiya Biomedical Company, USA).

Total protein, albumin, globulin, glucose, cholesterol, total lipid, urea, creatinine, the activities of aspartate amino transferase (AST) and alanine amino transferase (ALT), and also antioxidant status, total antioxidant capacity (TAC), glutathione S- 
transferase (GST), glutathione (GSH), glutathione peroxidase (GPx), superoxide dismutase activity(SOD), malondialdehyde (MDA) and thiobarbituric acid-reactive substances (TBARS) were determined using commercial medical kits. Blood testosterone concentration in the plasma was measured using the enzyme immunoassay method specified in the immunoassay commercial kits used.

\section{Semen Quality:}

Semen was collected three times during the experimental period randomly from 12 ganders per treatment per time using the abdominal massage method after a 6-wk adaptation period. The volume of each ejaculate was recorded after removal of the gel mass to the nearest $0.01 \mathrm{ml}$ using tuberculin. Sperm motility was estimated using phase contrast opticsat $40 \times$ and assessed from 0 to $100 \%$. A weak eosinformalin (10\% formalin) solution was used to evaluate the sperm concentration (Elkomy, 2003) using the improved Neubauer haemocytometer slide (Smith and Mayer, 1955). Total sperm output was calculated by multiplying the semen ejaculate volume by the semen concentration. Assessment of live and abnormal spermatozoa was performed using an eosin-nigrosine blue staining mixture (Blom, 1950). The percentage of live spermatozoa was determined using stains that penetrate cells with damaged membranes. The total number of motile sperm was calculated by multiplying the percentage of motile sperm by the total sperm output. The total functional sperm fraction (TFSF) was then calculated as the product of total sperm output multiplied by the percentage of motile sperm times the percentage of normal sperms (Correa and Zavos, 1996).

\section{Statistical Analysis:}

Analyses of variance was done by the least square analysis of variance utilizing the General Linear Model Procedure (SAS, 2004) using the replicate as the experimental unit. The model was as follows:

$\mathrm{Y}_{\mathrm{ij}}=\mu+\mathrm{T}_{\mathrm{i}}+\mathrm{e}_{\mathrm{ij}}$

Where $\mathrm{Y}_{\mathrm{ij}}=$ any observation of $\mathrm{i}^{\text {th }}$ bird within $\mathrm{j}^{\text {th }}$ treatment, $\mu=$ overall mean,

$\mathrm{T}_{\mathrm{i}}=$ effect of $\mathrm{i}^{\text {th }}$ treatment (i:1-4), $\mathrm{e}_{\mathrm{ijk}}=$ experimental error.

All percentages were transformed to their corresponding $\log 10$ before running the analyses. Significant differences among means were tested using the Duncan multiple range test (Duncan, 1955)

\section{RESULTS AND DISSCUTION}

\section{Water Quality:}

The results, in Table 1, indicated that TW had better quality than did WW in salinity, dissolved oxygen, total hardness, $\mathrm{Na}, \mathrm{K}$, $\mathrm{Ca}, \mathrm{Mg}$, and $\mathrm{Cl}$ minerals. Most of these minerals were excreted in the faeces. Also, the quality of well water was improved when exposed to the magnetic field. Increasing the strength of magnetic field to 6000 gauss resulted in better water quality than did 4000 gauss. Physically, exposure of the water to a magnetic field changes the water's properties including raising the $\mathrm{pH}$, conductivity, dissolved oxygen and the vital minerals besides decreasing the total hardness. Supporting to these results $\mathrm{Mg}$ Therapy (2000) mentioned that magnetized water become active, soft, with a higher $\mathrm{pH}$ (toward slight alkaline) and free of germs, which fulfil the requirements for water quality for poultry. Magnetized water causes the hydrogen-oxygen bond angle within the water molecule to be reduced from 104 to 103 degrees. This in turn causes the water molecule to cluster together in groups of 6-7 rather than in groups of 10-12. The smaller cluster leads to better absorption of water into the cell (Verma, 2011). Normal water has a $\mathrm{pH}$ level of about 7, whereas magnetized water can reach a $\mathrm{pH}$ of 7.8, (Lam, 2001). The increase in the salinity of well water (Table 1) could be attributed to increased soluble salts, which are associated with conductivity. This could be due to increasing organic matter from sewage or 
could be due to inorganic fertilizers, such as phosphates and nitrates, which overstimulate the growth of algae. It was reported that water passed through the magnetic field acquires a finer and more homogeneous structure (Tkachenko and Semyonova, 1995). This increases its fluidity and dissolving capacity for various constituents, such as minerals and vitamins (Kronenberg, 1985), consequently improving the biological activity of solutions and enhancing animal performance (Al-Mufarrej et al., 2005).

\section{Blood Cell Profile and Cellular Immunity:}

Data in Table (2) represent the effect of magnetic water on the blood picture and immunoglobulins of Egyptian geese males. Red blood cells and PCV\% were significantly increased $(\mathrm{p} \leq 0.05)$ for males that drank $\mathrm{WW}_{6000}$, and the haemoglobin for males that drank TW and $\mathrm{WW}_{6000}$ were also increased compared with those for the other treatments. Mean corpuscular MCV was higher $(\mathrm{p} \leq 0.05)$ in the males group on the WW than those of $\mathrm{TW}$ and $\mathrm{WW}_{6000}$ ones. Moreover, there were no significant differences between experimental groups with respect to MCHC was higher $(\mathrm{p} \leq 0.05)$ from the genders of TW group than from those of WW and WW 4000 groups, and was also higher for $\mathrm{WW}_{4000}$ than from those of WW without magnetic exposure. The decrease in RBCs of the genders in WW treatment could be attributed to changes in the kidney tissues. There were decreases in the production of the erythropoietin hormone, which is responsible for stimulating bone narrow to produce $\mathrm{RBCs}$ (Guyton and Hall, 2006). In addition, drinking WW caused varying degrees of anhydremia, resulting in an elevation of the specific gravity and the haematocrit value of the blood (El-Hassanein and El-Sherif, 1996). Stanis et al. (2001) and Al-Nueimi et al. (2015) found that magnetic water could increase the circulation of blood and the blood picture. Santwani (2000) pointed out that the improvements in RBCs, Hgb and PCV \% may be due to the effect of the magnetic water on the activity of the thyrotrophic stimulation hormone, and in turn, on thyroid hormones. In addition, Mile-Wski (2004) found that magnetic water decreases the viscosity of blood and increases the movement of blood in vessels, which caused high movement of $\mathrm{Hgb}$ and increased the movement of RBCs to transfer oxygen to cells (Kulish, 2004). Moreover, Rokicki (2006) showed that magnetic treatment causes an increase in the attraction of iron from the blood and thus increases number of RBCs and $\mathrm{Hb}$.

White blood cells for males did not significantly differ among all water treatments (TW, WW, $\mathrm{WW}_{4000}$ and $\left.\mathrm{WW}_{6000}\right)$. There were significant changes $(p \leq 0.05)$ among water treatments for lymphocytes, with them being the highest in the group of $\mathrm{WW}_{6000}$ and the lowest in the WW group. Water treatment did not influence the eosinophil or basophil percentages for the males. The increase in the percentage of lymphocytes due to drinking magnetic water is in harmony with that report by Johnson et al. (2001) who found that magnetic water improves the immune systems of animal.

Genders who drank $\mathrm{WW}_{6000}$ had the highest $(\mathrm{p} \leq 0.05)$ values of $\operatorname{IgG}$ and $\operatorname{IgM}$ compared with those of TW, WW and $\mathrm{WW}_{4000}$ groups. In addition, IgA was significantly $(\mathrm{p} \leq 0.05)$ increased in the males who received TW and $\mathrm{WW}_{6000}$ compared with WW and $\mathrm{WW}_{4000}$. IgG and $\operatorname{IgM}$ as a humeral immunity are the dominant immunoglobulin and thus the increase in $\operatorname{IgG}, \operatorname{IgM}$ and $\operatorname{IgA}$ could reflect the antibody status of the male geese. Similar results were reported by Tarasewicz et al. (2006). The results of increase in immunoglobulin (humeral immunity) of geese males that drank magnetized water $\left(\mathrm{WW}_{6000}\right)$ is in agreement with findings reported by Attia et al. (2015) who found that bucks drank magnetized water resulted in significant $(\mathrm{p} \leq 0.05)$ increases of $\operatorname{IgG}$ and $\operatorname{IgM}$ compared to 
those of bucks that drank unmagnetized water. Such magnetically treated water may decrease the microbial load and improve the immune system (Kronenberg, 1985). Thus the increases in cellular and humeral immunity are showing that the liver is capable of synthesizing enough globulins for immunity (Fortun-Lamothe and DrouetViard, 2002).

\section{Biochemical parameters:}

The influences of magnetic water on some of the blood constituents, liver and renal functions and the antioxidant status of geese males are presented in Table 3 . Well water significantly $(p \leq 0.05)$ decreased total protein, globulin and glucose compared with TW, but increased $(\mathrm{p} \leq 0.05)$ plasma cholesterol and total lipids, compared to the other treatments. Plasma albumin was significantly $(\mathrm{p} \leq 0.05)$ increased for geese males drank TW and $\mathrm{WW}_{6000}$ compared to WW with no statistical change with those

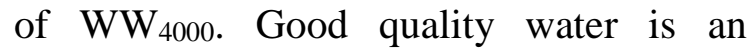
essential for life and is involved in many essential physiological functions, such as enzymatic function, nutrient transportation, and digestion, and it is an essential component of blood and tissues (Chiba, 2009). The results of increasing total protein for ganders drank $\mathrm{WW}_{6000}$ are in harmony with those reported by Morgan (1988) and by Shamsaldin and Alrawee (2012). In addition, Khalisa and Ali (2012) mentioned that magnetic water resulted in a significant elevation of total proteins, and this may be due to magnetic water being able to facilitate the transport of nutrients in the blood. Also the increase of plasma globulin from drinking magnetic water in the current study is similar to the findings of Shamsaldin and Alrawee (2012) who mentioned that magnetic water significantly increased blood globulin, and this may be due to effect of magnetic water in increasing the immune system's responses.

Plasma urea was significantly decreased for the males that drank $\mathrm{WW}_{6000}$ compared with those in the other treatments, while
WW treatment significantly increased plasma creatinine (a product of protein breakdown) compared with other treatments. Thus magnetic treatments resulted in better renal function than did TW and WW. In addition, AST was significantly lowered in geese that drank TW and magnetized water than in those who drank WW. In addition, 6000 gauss had a greater effect than 4000 gauss. ALT was significantly increased $(p \leq 0.05)$ in ganders received WW compared with the rest of the treatments. Thus the improvement in the quality of magnetized water (Table 1) was reflected in improved liver and kidney functions (Table 3) and this conclusion is supported by Soliman, (1993), Ezzat (1999) and Attia et al. (2015).

Total antioxidant capacity (TAC) was significantly superior for males drank $\mathrm{WW}_{6000}$ compared with those from the other treatments. In addition, males who drank either TW or $\mathrm{WW}_{6000}$ had the highest $(p \leq 0.05)$ values of plasma GST, GSH and GPX, and those received WW had the least, while those who drank $\mathrm{WW}_{4000}$ were intermediate. Males that drank WW had significantly $(\mathrm{p} \leq 0.05)$ the lowest value of SOD, and the highest values of MDA and TBARS compared with those in the other treatments. The present results indicate that magnetizing water significantly improved the antioxidant status of the geese and this was reflected on improved immune status and health. Supporting to our results of increasing antioxidants (TAC, GSH, GPX, SOD and GST) and decreasing lipid peroxidation (MDA and TBARS) concentrations from drinking magnetic water, Attia et al. (2015) pointed out an increase in the anti-oxidants (GSH, GPX, SOD and GST) and a decrease of TBARS and MDA due to magnetic water treatment suggested increasing stability of cell. These improvement in the function of liver, kidney and antioxidants enzymes could be explain based on the effect of magnetic treatments to improving solubility of 
minerals of water, which facilities the transfer of the nutrients via improving membrane permeability to animal cells, thus nutrients uptakes and utilization as the water is the media for all biological and metabolic reactions (El-Hanoun, 2014).

\section{Semen quality:}

Table 4 shows the plasma testosterone hormone concentration and semen quality traits of geese males subjected to magnetic water. Plasma testosterone hormone concentrations were significantly $(\mathrm{p} \leq 0.05)$ decreased in WW group compared to TW one. Magnetic treatment significantly increased plasma testosterone, and 6000 gauss was more effective than 4000 gauss. Records of ejaculate volume, sperm concentration, live sperm\%, normal sperm $\%$, and TFSF for males that drank WW were significantly lower than for those of males that received TW. In addition, magnetic treatments improved these parameters compared to WW treatment. Magnetizing the WW with 6000 gauss resulting in greater ejaculate volume, sperm motility (\%), sperm concentration, total sperm output, total motile sperms, and TFSF than 4000 gauss. However, there was no significant difference between 4000 or 6000 gauss for live sperm $(\%)$ and normal sperm $(\%)$. The present results are in harmony with those reported by Al-Nueimi and AL-Badry (2014) and by Attia et al. (2015). Magnetic water can increase the ability of the body to produce hormones like sexual hormones (Al-Nueimi et al., 2015), and sexual hormones improved semen characteristics (Alfonso et al., 2006). Weinbauer and Nieschlag (1992) also showed that a relatively high level of testosterone hormone is essential to maintain and sustain the growth of the testicles and the formation of sperm. The observed improvement in semen quality traits may be due to magnetic water's circulation of blood and oxygen, which improves gander's performance.

The current results of increasing the plasma testosterone hormone concentration and the improvement in semen quality traits are consistent with improving in the immune and antioxidant status of ganders receiving magnetic water. Supporting to this explanation, Mann and Lutwak-Mann (1981) showed that lipid peroxidation is one of the major reactions leading to phosphor lipid loss, membrane injury, and a decrease in spermatozoa motility in mammals. In addition, Alfonso et al. (2006) reported that using magnetic water in bulls lead to a significant increase in individual sperm motility. Olafsdottir and Reed (1988) showed that the GPx enzyme occupies a particularly crucial role in the antioxidant protection of the cell by altering hydrogen peroxidesin into less destructive components. Also, magnetic water is very effective as an anti-oxidant, protecting cells and tissues of the body from the harmful effects of various acids and oxygen ions (Rommerts, 1990; and AlNueimi and AL-Badry, 2014). Magnetic water induces a positive influence on the absorption and metabolism in the body and this in turn caused increases in the viability of cells and in immunity while decreasing lipid peroxidation biomarkers (MDA and TBRS), which improve the body's tolerance to pollutants and protect the body from the harmful effects of free radicals (Attia et al., 2015). Wang et al. (1998) reported that magnetic water increases efficiency in the biological and biochemical reactions of sperm cells. Al-Daraji and Aziz (2003) revealed that the quality and quantity of the semen of roosters that received magnetic water were significantly better than those of controls.

\section{CONCLUSION,}

Magnetizing well water with 6000 gauss for geese males, particularly in areas with limited water supplies, could be a useful tool for improving water quality and the geese's physiological, and immunological systems and their semen quality. 
Table (1): Analysis of water types used in the experiment

\begin{tabular}{|l|c|c|c|c|c|}
\hline Parameters & Unit & TW & WW & WW 4000 & WW \\
\hline Ph & - & 6.45 & 7.02 & 7.52 & 7.78 \\
Conductivity & Ms/Cm & 706 & 745 & 864 & 912 \\
Salinity & $\mathrm{Mg} / \mathrm{L}$ & 347 & 1016 & 1034 & 1058 \\
Dissolved Oxygen & $\mathrm{ppm}$ & 6.3 & 5.9 & 6.2 & 6.5 \\
Total hardness & $\mathrm{ppm}$ & 428 & 809 & 774 & 745 \\
Sodium $\left(\mathrm{Na}^{ \pm}\right)$ & $\mathrm{ppm}$ & 6.9 & 69.8 & 77.9 & 86.3 \\
Potassium $\left(\mathrm{K}^{ \pm}\right)$ & $\mathrm{ppm}$ & 1.7 & 19.8 & 22.4 & 25.3 \\
Calcium $\left(\mathrm{Ca}^{2 \pm}\right)$ & $\mathrm{ppm}$ & 115.6 & 218.7 & 234.2 & 241.5 \\
Magnesium $\left(\mathrm{Mg}^{2 \pm}\right)$ & $\mathrm{ppm}$ & 109.6 & 215.4 & 197.6 & 173.4 \\
Chloride $\left(\mathrm{Cl}^{-}\right)$ & $\mathrm{ppm}$ & 3.2 & 15.7 & 14.3 & 11.2 \\
Carbonate $\left(\mathrm{CO}^{-}\right)$ & $\mathrm{ppm}$ & 3.5 & 2.1 & 3.2 & 3.4 \\
Bicarbonate $\left(\mathrm{HCO}^{-}\right)$ & $\mathrm{ppm}$ & 12.7 & 88.6 & 23.4 & 19.5 \\
Nitrates & $\mathrm{ppm}$ & 0.00 & 0.00 & 0.30 & 0.70 \\
\hline
\end{tabular}

TW tap water, WW well water, $\mathrm{WW}_{4000}$ well water exposed to magnetic field of 4000 gauss, $\mathrm{WW}_{6000}$ well water exposed magnetic field 6000 gauss.

Table (2): Effects of magnetic water treatment on blood cell constituent of Egyptian geese males (mean \pm SE)

\begin{tabular}{|c|c|c|c|c|}
\hline \multirow[t]{2}{*}{ Traits } & \multicolumn{4}{|c|}{ Treatments } \\
\hline & TW & $\mathbf{W W}$ & $\mathbf{W W}_{4000}$ & WW6000 \\
\hline \multicolumn{5}{|c|}{ Red blood cell profile $^{1}$} \\
\hline $\begin{array}{l}\text { Red blood cells } \mathrm{RBC} \\
\left(\mathrm{x} 10^{\left.6 / \mathrm{mm}^{3}\right)}\right.\end{array}$ & $5.46 \pm 0.18^{c}$ & $4.69 \pm 0.22^{\mathrm{d}}$ & $5.98 \pm 0.27^{b}$ & $6.42 \pm 0.36^{\mathrm{a}}$ \\
\hline Hemoglobin $\mathrm{Hb}$ (g/dl) & $10.93 \pm 0.12^{\mathrm{a}}$ & $7.81 \pm 0.17^{\mathrm{c}}$ & $9.11 \pm 0.10^{\mathrm{b}}$ & $11.06 \pm 0.15^{\mathrm{a}}$ \\
\hline Hematocrit Ht (\%) & $32.61 \pm 2.7^{\mathrm{b}}$ & $29.54 \pm 2.2^{\mathrm{c}}$ & $33.17 \pm 3.4^{\mathrm{b}}$ & $35.61 \pm 2.9^{\mathrm{a}}$ \\
\hline Mean corpuscular MCV (fl) & $109.7 \pm 9.8^{\mathrm{b}}$ & $168.4 \pm 12.8^{\mathrm{a}}$ & $139.6 \pm 11.7^{\mathrm{ab}}$ & $120.8 \pm 10.5^{b}$ \\
\hline $\begin{array}{l}\text { Mean corpuscular } \\
\text { hemoglobin } \mathrm{MCH}(\mathrm{pg})\end{array}$ & $24.9 \pm 4.5$ & $26.1 \pm 4.4$ & $23.5 \pm 5.1$ & $26.8 \pm 4.8$ \\
\hline $\mathrm{MCHC}(\%)$ & $22.8 \pm 4.3^{\mathrm{a}}$ & $13.9 \pm 2.9^{c}$ & $16.6 \pm 4.1^{\mathrm{b}}$ & $21.1 \pm 3.9^{\mathrm{ab}}$ \\
\hline \multicolumn{5}{|c|}{ Cellular immunity } \\
\hline $\begin{array}{l}\text { White blood cells WBCs } \\
\left(\times 10^{3} / \mathrm{mm}^{3}\right)\end{array}$ & $25.6 \pm 0.16$ & $24.7 \pm 0.13$ & $26.0 \pm 0.12$ & $25.1 \pm 0.14$ \\
\hline Lymphocyte (\%) & $64.2 \pm 1.7^{\mathrm{b}}$ & $61.1 \pm 1.3^{\mathrm{c}}$ & $65.5 \pm 1.5^{\mathrm{ab}}$ & $66.3 \pm 1.6^{\mathrm{a}}$ \\
\hline Monocyte (\%) & $4.29 \pm 1.3^{\mathrm{a}}$ & $4.32 \pm 1.6^{\mathrm{a}}$ & $3.55 \pm 1.5^{\mathrm{b}}$ & $3.21 \pm 1.7^{\mathrm{c}}$ \\
\hline Eosinophil (\%) & $1.66 \pm 0.01$ & $1.67 \pm 0.02$ & $1.65 \pm 0.02$ & $1.64 \pm 0.01$ \\
\hline Basophil (\%) & $1.62 \pm 0.02$ & $1.63 \pm 0.02$ & 1.620 .01 & $1.64 \pm 0.02$ \\
\hline \multicolumn{5}{|c|}{ Immunoglobulins } \\
\hline $\operatorname{IgG}(\mathrm{mg} / \mathrm{ml})$ & $4.22 \pm 0.142^{\mathrm{b}}$ & $3.36 \pm 0.117^{\mathrm{d}}$ & $4.01 \pm 0.128^{c}$ & $4.47 \pm 0.139^{\mathrm{a}}$ \\
\hline $\operatorname{IgM}(\mathrm{mg} / \mathrm{ml})$ & $1.30 \pm 0.087^{\mathrm{b}}$ & $0.81 \pm 0.069^{d}$ & $1.06 \pm 0.074^{\mathrm{c}}$ & $1.47+0.091^{\mathrm{a}}$ \\
\hline $\operatorname{IgA}(\mathrm{mg} / \mathrm{ml})$ & $0.502 \pm 0.053^{\mathrm{a}}$ & $0.336 \pm 0.042^{\mathrm{c}}$ & $0.447 \pm 0.048^{\mathrm{b}}$ & $0.510 \pm 0.062^{\mathrm{a}}$ \\
\hline
\end{tabular}

$\mathrm{a}, \mathrm{b}, \mathrm{c}, \mathrm{d}$ Differences among means within a column within each factor not sharing similar superscripts are significantly at $(\mathrm{p} \leq 0.05), \mathrm{SE}=\mathrm{Standard}$ error, $\mathrm{TW}=$ tap water, $\mathrm{WW}=$ well water, $\mathrm{WW}_{4000}=$ well water exposed to magnetic field of 4000 gauss, $\mathrm{WW}_{6000}=$ well water exposed magnetic field 6000 gauss, $\mathrm{IgG}=$ Gamma immunoglobulin, $\mathrm{IgM}=$ Muimmunoglobulin, $\mathrm{IgA}=$ Alpha immunoglobulin, $\mathrm{MCHC}=$ Mean corpuscular hemoglobin concentration . 
Geese- Magnetic water- Semen quality- Blood components- Immunity.

Table (3): Effects of magnetic water treatment on blood biochemical constituents and antioxidant status of Egyptian geese males (mean \pm SE)

\begin{tabular}{|c|c|c|c|c|}
\hline \multirow[t]{2}{*}{ Traits } & \multicolumn{4}{|c|}{ Treatments } \\
\hline & TW & WW & $W_{4000}$ & WW6000 \\
\hline \multicolumn{5}{|c|}{ Blood biochemical constituents } \\
\hline Total protein $(\mathrm{g} / \mathrm{dl})$ & $6.72 \pm 0.62^{\mathrm{a}}$ & $5.13 \pm 0.48^{c}$ & $6.02 \pm 0.51^{\mathrm{b}}$ & $6.66 \pm 0.39^{\mathrm{a}}$ \\
\hline Albumin $(\mathrm{g} / \mathrm{dl})$ & $3.97 \pm 0.36^{\mathrm{a}}$ & $3.32 \pm 0.41^{\mathrm{b}}$ & $3.51 \pm 0.3^{\mathrm{ab}}$ & $3.82 \pm 0.53^{\mathrm{a}}$ \\
\hline Globulin $(\mathrm{g} / \mathrm{dl})$ & $2.75 \pm 0.40^{\mathrm{a}}$ & $1.81 \pm 0.56^{\mathrm{c}}$ & $2.51 \pm 0.44^{\mathrm{b}}$ & $2.84 \pm 0.49^{\mathrm{a}}$ \\
\hline Glucose $(\mathrm{g} / \mathrm{dl})$ & $187.4 \pm 7.3^{\mathrm{a}}$ & $152.8 \pm 6.6^{\mathrm{b}}$ & $160.4 \pm 5.9^{\mathrm{ab}}$ & $168.2 \pm 7.5^{\mathrm{ab}}$ \\
\hline Cholesterol $(\mathrm{mg} / \mathrm{dl})$ & $88.9 \pm 1.9^{c}$ & $116.7 \pm 2.4^{\mathrm{a}}$ & $95.4 \pm 2.8^{\mathrm{b}}$ & $90.3 \pm 2.6^{\mathrm{c}}$ \\
\hline Total lipids (g/dl) & $3.12 \pm 0.28^{\mathrm{c}}$ & $3.89 \pm 0.37^{\mathrm{a}}$ & $3.51 \pm 0.21^{\mathrm{b}}$ & $3.07 \pm 0.35^{\mathrm{c}}$ \\
\hline \multicolumn{5}{|c|}{ Renal function } \\
\hline Urea $(\mathrm{mg} / \mathrm{dl})$ & $23.9 \pm 0.30^{\mathrm{b}}$ & $27.4 \pm 0.46^{\mathrm{a}}$ & $23.3 \pm 0.35^{\mathrm{b}}$ & $21.2 \pm 0.52^{\mathrm{c}}$ \\
\hline Creatinine $(\mathrm{mg} / \mathrm{dl})$ & $1.28 \pm 0.06^{\mathrm{b}}$ & $1.48 \pm 0.04^{\mathrm{a}}$ & $1.35 \pm 0.05^{\mathrm{b}}$ & $1.27 \pm 0.03^{\mathrm{b}}$ \\
\hline Urea/ Creatinin & $18.7 \pm 0.22^{\mathrm{a}}$ & $18.6 \pm 0.17^{\mathrm{a}}$ & $17.3 \pm 0.21^{\mathrm{b}}$ & $16.7 \pm 0.16^{\mathrm{b}}$ \\
\hline \multicolumn{5}{|c|}{ Liver function } \\
\hline $\operatorname{AST}(\mathrm{IU})$ & $31.4 \pm 0.52^{\mathrm{c}}$ & $35.6 \pm 0.73^{\mathrm{a}}$ & $33.1 \pm 0.38^{b}$ & $31.9 \pm 0.44^{\mathrm{c}}$ \\
\hline ALT (IU) & $13.3 \pm 0.47^{b}$ & $15.7 \pm 0.38^{\mathrm{a}}$ & $12.6 \pm 0.67^{b}$ & $12.9 \pm 0.51^{\mathrm{b}}$ \\
\hline AST/ ALT & $2.35 \pm 0.07^{\mathrm{c}}$ & $2.24 \pm 0.04^{\mathrm{d}}$ & $2.63 \pm 0.08^{\mathrm{a}}$ & $2.46 \pm 0.06^{\mathrm{b}}$ \\
\hline \multicolumn{5}{|c|}{ Antioxidant indices } \\
\hline $\mathrm{TAC}, \mathrm{MM} / \mathrm{L}$ & $155.1 \pm 2.19^{c}$ & $137.8 \pm 3.11^{\mathrm{d}}$ & $163.5 \pm 3.24^{b}$ & $171.9 \pm 2.94^{\mathrm{a}}$ \\
\hline GST (IU) & $1.67 \pm 0.002^{\mathrm{a}}$ & $1.30 \pm 0.001^{\mathrm{c}}$ & $1.49 \pm 0.002^{\mathrm{b}}$ & $1.61 \pm 0.003^{\mathrm{a}}$ \\
\hline GSH (mg/dl) & $24.5 \pm 0.481^{\mathrm{a}}$ & $17.3 \pm 0.336^{\mathrm{c}}$ & $20.3 \pm 0.446^{\mathrm{b}}$ & $23.9 \pm 0.435^{\mathrm{a}}$ \\
\hline GPX (mg/L) & $4.87 \pm 0.205^{\mathrm{a}}$ & $3.54 \pm 0.148^{c}$ & $4.31 \pm 0.211^{\mathrm{b}}$ & $5.01 \pm 0.198^{\mathrm{a}}$ \\
\hline SOD (IU) & $8.17 \pm 0.174^{\mathrm{a}}$ & $6.08 \pm 0.142^{\mathrm{d}}$ & $6.82 \pm 0.158^{c}$ & $7.64 \pm 0.169^{b}$ \\
\hline $\mathrm{MDA}(\mathrm{nmol} / \mathrm{ml})$ & $0.758+0.004^{\mathrm{c}}$ & $1.412+0.006^{\mathrm{a}}$ & $0.934+0.003^{b}$ & $0.772+0.004^{\mathrm{c}}$ \\
\hline TBARS $(\mathrm{nmol} / \mathrm{ml})$ & $0.896 \pm 0.002^{b}$ & $0.942 \pm 0.001^{\mathrm{a}}$ & $0.885 \pm 0.003^{b}$ & $0.863 \pm 0.002^{c}$ \\
\hline
\end{tabular}

$\mathrm{a}, \mathrm{b}, \mathrm{c}, \mathrm{d}$ Differences among means within a column within each factor not sharing similar superscripts are significantly at $(\mathrm{p}<0.05), \mathrm{SE}=\mathrm{Standard}$ error, $\mathrm{n}=16$ samples per treatment. $\mathrm{TW}=$ tap water, $\mathrm{WW}=$ well water, $\mathrm{WW}_{4000}=$ well water exposed to magnetic field of 4000 gauss, $\mathrm{WW}_{6000}=$ well water exposed magnetic field 6000 gauss. AST $=$ Aspartate aminotransferase, ALT $=$ alanine aminotransferase, $\mathrm{TAC}=$ total antioxidant capacity, GST=lutathione S-transferase, (GSH) glutathione content, $\mathrm{GPx}=$ glutathione peroxidase, $\mathrm{SOD}=$ superoxide dismutase, $\mathrm{MDA}=$ malondialdehyde, TBARS $=$ thiobarbituric acid reactive substances. 
Table (4): Effects of water treatments on testosterone hormone and semen quality traits of Egyptian geese males (mean \pm SE)

\begin{tabular}{|c|c|c|c|c|}
\hline \multirow[t]{2}{*}{ Traits } & \multicolumn{4}{|c|}{ Treatments } \\
\hline & TW & WW & WW4000 & WW6000 \\
\hline Testosterone, $\mathrm{ng} / \mathrm{ml}$ & $0.514 \pm 0.039^{\mathrm{a}}$ & $0.442 \pm 0.047^{\mathrm{c}}$ & $0.483 \pm 0.051^{\mathrm{b}}$ & $0.517 \pm 0.032^{\mathrm{a}}$ \\
\hline Ejaculate volume, $\mathrm{ml}$ & $0.76 \pm 0.012^{\mathrm{c}}$ & $0.68 \pm 0.11^{\mathrm{d}}$ & $0.94 \pm 0.014^{b}$ & $1.11 \pm 0.013^{\mathrm{a}}$ \\
\hline Sperm motility, \% & $69.4 \pm 1.63^{\mathrm{bc}}$ & $65.3 \pm 1.14^{\mathrm{c}}$ & $76.5 \pm 1.19^{\mathrm{b}}$ & $86.5 \pm 1.39^{\mathrm{a}}$ \\
\hline Sperm concentration, $\times 10^{6}$ & $235.3 \pm 8.11^{\mathrm{c}}$ & $218.6 \pm 7.23^{\mathrm{d}}$ & $346.4 \pm 7.12^{\mathrm{b}}$ & $407.9 \pm 9.06^{\mathrm{a}}$ \\
\hline Total sperm output, $\times 10^{6}$ & $179.5 \pm 6.1^{\mathrm{c}}$ & $171.4 \pm 5.9^{c}$ & $330.9 \pm 11.4^{\mathrm{b}}$ & $454.1 \pm 13.6^{\mathrm{a}}$ \\
\hline Total motile sperm, $\times 10^{6}$ & $124.5 \pm 5.8^{\mathrm{c}}$ & $119.4 \pm 2.4^{\mathrm{c}}$ & $253.7 \pm 9.8^{b}$ & $394.6 \pm 14.1^{\mathrm{a}}$ \\
\hline Live sperm, \% & $72.5 \pm 5.8^{\mathrm{b}}$ & $67.1 \pm 4.4^{\mathrm{c}}$ & $75.7 \pm 4.7^{\mathrm{ab}}$ & $88.5 \pm 4.3^{\mathrm{a}}$ \\
\hline Normal sperm, \% & $77.5 \pm 0.46^{\mathrm{b}}$ & $70.5 \pm 0.38^{c}$ & $86.1 \pm 0.71^{\mathrm{a}}$ & $88.9 \pm 0.59^{\mathrm{a}}$ \\
\hline TFSF & $96.5 \pm 3.11^{\mathrm{c}}$ & $84.2 \pm 2.78^{\mathrm{d}}$ & $218.4 \pm 7.14^{b}$ & $350.8 \pm 10.47^{\mathrm{a}}$ \\
\hline
\end{tabular}

$\mathrm{a}, \mathrm{b}, \mathrm{c}, \mathrm{d}$ Differences among means within a column within each factor not sharing similar superscripts are significantly at $(\mathrm{p} \leq 0.05), \mathrm{SE}=$ Standard error, $\mathrm{n}=36$ samples per treatment for most of traits except that for plasma testosterone which was equal to $=16$ samples per treatment.

$\mathrm{TFSF}=$ Total functional sperm fraction. $\mathrm{TW}=$ tap water, $\mathrm{WW}=$ well water, $\mathrm{WW}_{4000}=$ well water exposed to magnetic field of 4000 gauss, $\mathrm{WW}_{6000}=$ well water exposed magnetic field 6000 gauss

\section{REFERENCES}

Al-Daraji, H.; and Aziz, A., 2003. The use of magnetically treated water for improving semen traits of roosters. Dep. of Ani. Resour. Coll. of Agri. Univ. of Baghdad. pp: 80-91.

Al-Daraji, H. J.; and Aziz, A. A., 2008. The use of magnetically treated water for improving semen traits of roosters. Al-Anbar J. Vet. Sci., 1: 79-92.

Al-Daraji, H. J.; and Aziz, A. A., 2009. Effect of magnetized water on certain seminal plasma traits of Hy-Line Brown roosters. Diyala Agric. Sci. J., 1: 1-21.

Alfonso, C. M.; Mario, O. R.; Reinaldo, S. P.; and Enrique, A. B., 2006. Calidad del semen en toros que consumen agua con tratamiento, Revista Electrónica de Veterinaria Redvet 7(11): 1695-7504.

Al-Mufarrej, S.; Al-Batshan, H. A.; Shalaby, M. I.; and Shafey, T. M., 2005. The effects of magnetically treated water on the performance and immune system of broiler chickens. Int. J. Poult. Sci., 4: 96-102.

Al-Nueimi, S. H.; and AL-Badry, K. I., 2014. Effect of magnetic water drinking on sexual desire, semen characteristics and freezability of semen for holstein bulls born in iraq. Int. J. Res. Med. Health Sci., 4: 18-29.

Al-Nueimi, S. H.; Al-Badry, K. I.; Atteyh, A. J.; Al-Sabeea, W. S.; Ibrahim, F. F.; and Rajab, B., 2015. Effect of magnetic water drinking on testis dimension, scrotal circumference and blood parameters of Holstein bulls born in Iraq. Adv. Anim. Vet. Sci. 3: 413-417.

AOAC, Association of Official Analytical Chemists 2007. Official methods of analysis (18 ${ }^{\text {th }}$ Ed) Washington, D.C., U.S.A.

Attia, Y. A.; Abd El-Hamid, A.; ElHanoun, E. A. M.; Al-Harthi, M. A.; Abdel-Rahman, G. M.; and Abdella, M. M., 2015. Responses of the fertility, semen quality, blood constituents, immunity and antioxidant status of rabbit bucks to type and magnetizing of water. Ann. Anim. Sci., 15: 387-407.

Blom, E., 1950. A one-minute live-dead sperm stain by means of eosin-nigrosin. J. Fertil. Steril., 1: 176-177.

Chiba, L. I., 2009. Animal Nutrition hand book. Second revision. htt:umkcarnivores 3.files.word 
press.com/2012/02/animal-nutrition 2pdf. Downloaded August 20, 2013.

Correa, J. R.; and Zavos, P. M., 1996. Preparation and recovery of frozen thawed bovine spermatozoa via various sperm selection techniques employed in assisted reproductive technologies. Theriogenology, 46: 1225-12232.

Duncan, D. B., 1955. Multiple range and multiple F. test. Biometrics, 11: 1-42.

Eilers, R. I., 1967. Notification of final adaptation of an international method and standard solution for hemoglobin omety: specific for preparation of standard solution. American J. Clini. Patho., 47: 212-314.

El-Hanoun, A. M., 2014. Effect of magnetically treated water on some productive and reproductive performance in Egyptian geese. $7^{\text {th }}$ International Poultry Conference Proceeding, 3 - 6 November, Ain Sukhna, Red Sea - Egypt, pp: 93-103.

El-Hassanein, E. E.; and El-Sherif, $M$. M. A., 1996. Effect of prolonged drinking saline water on the blood picture of growing lambs. $4^{\text {th }}$ Sci. Cong. Proc., April 3-6 Vet. Med. J., 44(2): 435-441.

Elkomy, A. E., 2003. Physiological studies on Gibberellic Acid (GA) and reproductive functions 3 of adult fowl. Ph.D. Thesis, Faculty of Agriculture, Alexandria University.

Ezzat, W., 1999. Effect of some minerals in the drinking water on physiological process of broiler production. Ph.D. Thesis Fac. of Agric. Zagazig Univ., Egypt.

Fortun-Lamothe, L.; and Drouet-Viard, F., 2002. Review: II - Diet and immunity: current state of knowledge and research prospects for the rabbit. World Rabbit Sci., 10: 25-39.

Fayez, M.; Marai, I.; Alnaimy, M.; and Habeeb, A., 1994. Effect of salinity of drinking water on farm animals. In: Ap Dewi, I.; Axford, R. F. E.; Fayez, M.; Marai, I.; Omed, h. (eds): Pollution in livestock Production Systems. Wallingford, CAB International, pp: 119-135.

Guyton, A. C.; and Hall, G. E., 2006. Text book of Medical Physiology. $6^{\text {th }}$ Edn. London.

Hassan, Amal, M., 2013. Semen quality and hematology parameters of White Leghorn cocks drinking saline water under hot desert conditions. Egypt. Poult. Sci., 33(1): 163-179.

Hepler, O. E., 1966. Manual of clinical laboratory methods. Thomas, sparing field. Illinois, USA.

Johnson, M. T.; Vanscoy-Cornett, A.; and Vesper, D. N., 2001. Electromagnetic fields used clinically to improve bone healing also impact lymphocyte proliferation in vitro. Biomed. Sci. Instrument, 37: 215-220.

Kegley, S. E.; and Andrews, J., 1998. The Chemistry of Water, published by University Science Books, Sausalito, CA, USA.

Khalisa, K.; and Ali, A. M., 2012. Effect of magnetic water on some physiological aspects of adult male rabbits. Proceeding of eleventh Veterinary Scientific Conference. pp: 120-126.

Kronenberg, K. J., 1985. Experimental evidence for effects of magnetic fields on moving water. IEEE Transaction on Magnetics, 21: 2059-2061.

Kulish, P., 2004. Conquering pain advanced healing and wellbeing. The art of healing with biomagnetism. (mgimage@magnetizer.net).

Lam, M., 2001. Magnetized water. (www.DrLam.com)

Lin, I. J.; and Yotvat, J., 1989. Exposure of irrigation water to magnetic field with controlled power and direction, effects on grapefruit. Alon Hanotea, 43: 669674.

Lock, J., 1986. Magnetic treatment offers cost-effective descaling Proceeding, August-Sept., pp: 24-25. 
Lucas, A. M.; and Jamroz C., 1961. Atlas of Avian Hematology. Agriculture Monograph. 25, USDA, Washington, DC, USA.

Mann, T.; and Lutwak-Mann, C., 1981. Male reproductive function and semen. Springer Verlag, Berlin, Germany

Marai, I. F. M.; Habeeb, A. A.; and Gad, A. E., 2005. Tolerance of imported rabbits grown as meat animals to hot climate and saline drinking water in the subtropical environment of Egypt. Anim. Sci., 81: 115-123.

Mg-Therapy, 2000. Magnetic water. http://www. Thepainrelivers. Com.au/about-magnetic-therapy-painrelife.php.

Mile-Wski, S., 2004. Efekty stymulacji owiec pulsujacym polem elektromagnetycznym. Rozprawy imonografie UWM. Olsztyn, 100: 1-69.

Morgan, T., 1988. Therapeutic magnetism, yesterday and today 4137 chapman way, Pleasanton. pp: 9-23.

Mustafa, M. M., 2007. Effect of magnetic technology on water treated on the productive performance and physiological embryos and broiler and chicken chicks hatched in different environmental conditions. Ph.D. Thesis, Faculty of Agriculture, Baghdad University.

Olafsdottir, K.; and Reed, D. J., 1988. Retention of oxidized glutathione by isolated rat liver mitochondria during hydroperoxide treatment. Biochim. Biophys. Acta, 964: 377-382.

Rokicki, R., 2006. Magnetic fields and electro polished metallic implants. Medical device and diagnostic industry. (www.devicelink.com).

Rommerts, F. F. G., 1990. Testosterone, an overview of biosynthesis, transport, metabolism, and action. In: Testosterone, action, deficiency and substitution, 1st ed., Nieschlag E., H.M. Behre (Eds). p: 3, Springer-Verlag, Berlin, Germany.
Santwani, M. T., 2000. The art of magnetic healing water. The source for alternative medicine and holistic health. www.indiangyan.com

SAS, 2004. SAS User's guide statistics. Release 9.1. SAS institute INC., Cary. NC, USA.

Scollan, N. D.; Greenwood, P. L.; Newbold, C. J.; Yáñez Ruiz, D. R.; Shingfield, K. J.; Wallace, R. J.; and Hocquette, J. F., 2010. Future research priorities for animal production in a changing world. Anim. Prod. Sci., 51: 15.

Shamsaldin, K. Z.; Al-Rawee, E. A., 2012. Effect of magnetic water on productive efficiency of Awassi sheep. Proceeding of sixth Veterinary Scientific Conference 26. pp: 129-135.

Smith, J. T.; and Mayer, D. T., 1955. Evaluation of sperm concentration by the hemocytometer method. Fertil Steril, 6: 271-275.

Smith, H., 2005. Magnetic Water. FAQs. Magnetism Health Powers, The Doctor, Prescription for Health living, 9(3): 54.

Soliman, M. M., 1993. Some reproductive and physiological studies on domestic fowls. Ph.D. Thesis Fac. of Agric. Zagazig Univ., Egypt.

Stanis, A. W; Wiesaw, S.; Andrzej, D.; and Andrzej, R., 2001. Effect of pulsed electromagnetic magnetic field $(9.4 \mathrm{~T})$ in rats. J. Magnetic electronic resonancelmaging, 12: 122-139.

Tarasewicz, Z.; Szczerbinska, D.; Majewska, D.; Danczak, A.; LigockI, M.; and Wol-ska, A., 2006. The effect of magnetic field on hatchability of Japanese quail eggs. Czech J. Anim. Sci., 51: 355-360.

Tkachenko, Y.; and Semyonova, N., 1995. Your way to health: Magnetic water plus separate nutrition" In:Mysteries of Magnetic Energies A Collection of Scientific Works on the Usage of Magnetic Energies in Medical Practice. Yuri P.Tkachenko (ed), Printing Emirates, Printing \& Publishing- 
Sharjah, UAE. 1995. Part 6, pp: 225244.

Verma, S. S., 2011. Magnetic water treatment. Chemical Business Journal, January, 13-16.

Wang, Y.; Chao, F.; and Yang, T., 1998. Influence of magnetized water on growth and development and physiological characteristics of fluecured tobacco. Acta Agric. Univ. Henanensis; 32(3): 263-269.

Weinbauer, G. F.; and Nieschlag, E. 1992. The role of testosterone in spermatogenesis. pp: 143-186 in
Testosterone Action - Deficiency Substitution Second Edition: S. Nieschlag. Springer

Zaghloul, A. A.; Al-Hameed, Afaf A.; and El-Bahrawy, K. A., 2011. Effect of drinking saline water deprivation on semen quality and some blood parameters of Barki rams. Egypt. J. Basic Appl. Physiol., 10(2): 223-235.

Zhao, J.; Cui, X. U.; and Mingyu, S. H. I., 2002. Effect of Magnetized DrinkingWater on Mouse Testis. Chinese J. Laboratory Anim. Sci., 2002-1.

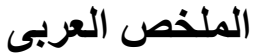

$$
\begin{aligned}
& \text { تأثير مغتطه مياه الأبار على مكونات الدم، الاستجابه المناعيه وجوده السائل المنوى فى ذكور الإوز } \\
& \text { المصرى المبنابه } \\
& \text { على محمد الحنون1؛ وسام أديب فارس1؛ يوسف عبد الوهاب عطيه3،2؛؛ محمد مصطقى عبد الللاه1 }
\end{aligned}
$$

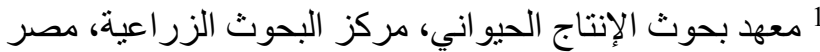

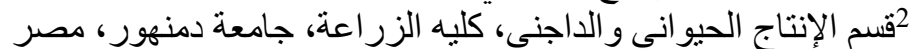

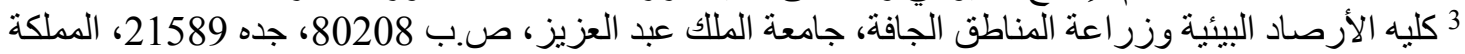

$$
\begin{aligned}
& \text { العربية السعودية العادية العزية }
\end{aligned}
$$

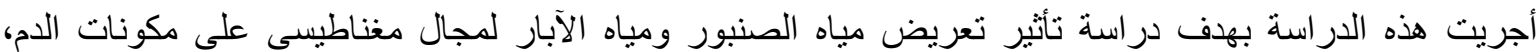



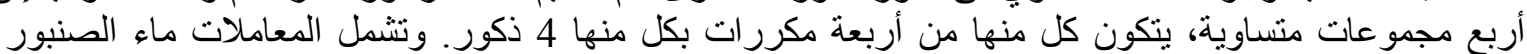

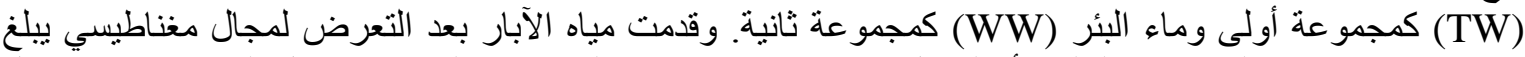

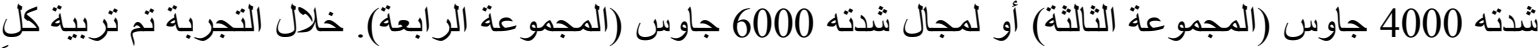

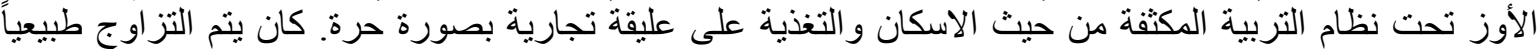

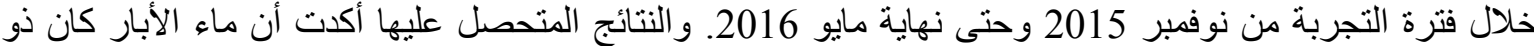

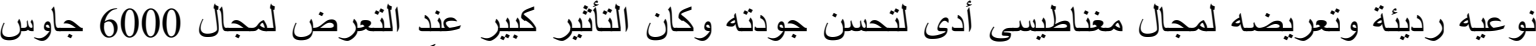

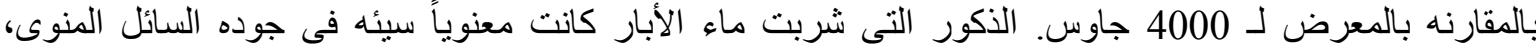

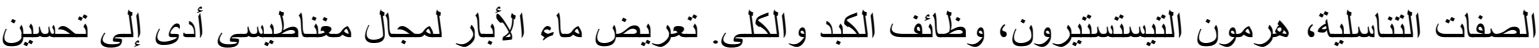

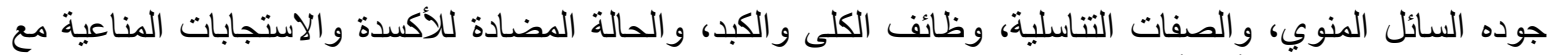

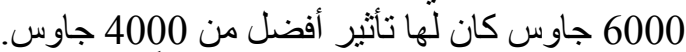


الفسيولوجية و المناعية للأوز الذئى يشرب ماء الأبار . 